\title{
EFFECT OF DRIP IRRIGATION FREQUENCY ON SOIL MOISTURE DISTRIBUTION AND WATER USE EFFICIENCY FOR SPRING POTATO PLANTED UNDER DRIP IRRIGATION IN A SANDY SOIL
}

\author{
M. A. Kassem
}

\section{ABSTRACT}

The current study was carried out at Agricultural and Veterinary Research Station, Faculty of Agriculture and Veterinary Medicine, Qassim University, Kingdom of Saudia Arabia during 2003 and 2004 spring growing seasons. The objective of this study is to investigate the effect of irrigation frequency on irrigation water depth " $d$ ", wetted area width "W" and depth " $D$ ", potato root distribution, soil moisture distribution, water losses by deep percolation, potato tuber yield and water use efficiency. Treatments consisted of seven different drip irrigation frequency: "IF2/1" (irrigating every half day), "IF $1 / 1$ " (irrigating every day), "IF $1 / 2$ " (irrigating every 2 days), "IF $1 / 3$ " (irrigating every 3 days), "IF $1 / 4$ " (irrigating every 4 days), "IF1/6" (irrigating every 6 days) and "IF $1 / 8$ " (irrigating every 8 days). All treatments received the same total amount of drip irrigation water. The results indicated that drip irrigation frequency affected all parameters of this study. Irrigation water depth " $d$ " was increased with decreasing irrigation frequency from IF $2 / 1$ to IF 1/8, depending on potato growing stage and climatic conditions. Also, wetted area width "W" and depth " $D$ ", water losses by deep percolation were increased with decreasing irrigation frequency depending on irrigation water depth " $d$ ". Soil moisture distribution was effected by irrigation frequency depending on potato growing stage, soil depth and the depth of applied water for each irrigation. Potato root growth was also affected by drip irrigation frequency: the higher the frequency, the lower was the root weight density (RWD). A value of 51-72\% of RWD was found in the 0 $10 \mathrm{~cm}$ soil layer at all treatments. High frequency irrigation enhanced potato tuber growth, field water use efficiency (FWUE) and crop water use efficiency (CWUE).

Assoc. Prof. of Ag. Eng., Fac. Ag., Cairo Univ. 
Reducing irrigation frequency from IF $1 / 1$ to IF $1 / 8$ resulted in significant yield reductions by $79.5 \%$ and $79.66 \%$ in 2003 and 2004 seasons, respectively. For total ETc, heigh difference was found among the different irrigation frequency treatments.

\section{INTRODUCTION}

$\mathrm{P}$ otato is one of the most important vegetables in the world. It is quite sensitive to water stress. Al-Qassim region produces about half of the potato produced in Saudi Arabia. In Qassim region, it is generally planted in furrows and irrigated by central pivot sprinkler systems. Drip irrigation is often preferred over other irrigation methods because of its high farm water-application efficiency on account of reducing losses by surface evaporation and deep percolation. Because of its higher water application frequency, concentration of salts remains manageable in the rooting zone (Mantell et al., 1985). Drip irrigation saves irrigation water and has the highest value of potato water use efficiency compared with sprinkler irrigation system( $\underline{\text { Kassem }}$, M.A and A. Elmeshelah 2003).

Irrigation frequency is one of the most important factors in drip irrigation scheduling. Due to the great changes in soil moisture distribution along the growth period, crop yields may be different when the same quantity of water is applied under different irrigation frequencies. High irrigation frequency may provide more desirable moisture stability conditions for water movement in soil and for the uptake by roots (Segal et al., 2000). Schwartzman and Zur. 1986. found that wetted soil width and depth were affected by duration of water application and discharge rate. Some crops have shown positive responses to high frequency drip irrigation in several experiments (Segal et al., 2000 and Sharmasarkar et al., 2001). However, seeming inconsistencies as what frequency might be optimum which could be found in the literature. Dalvi et al. (1999) found that the maximum yield was obtained at every second day frequency. Pitts et al. (1991) found that two days drip irrigation frequencies (three times per day and one time per day) had no effect on tomato yield. However, root length density (total root length per soil volume) was significantly affected by irrigation treatment for soil layer $0-0.15 \mathrm{~m}$ depth, since more 
frequent irrigation treatment had less root length density. Meshkat et al. (2000) went one-step further by pointing out that an irrigation regime with excessively high frequency could cause the soil surface to remain wet with first stage evaporation persisting most of the time resulting in a maximum rate of water loss. Evidence indicates that root systems under partial soil wetting are dominated by wetting patterns under the drippers (Clothier and Green, 1994 and Coelho and Or, 1996). These limited root systems might affect crop growth ., however, when the main nutrients are applied through irrigation system.

Understanding soil water distribution, potato root distribution and water uptake patterns has become increasingly important in developing modern environmentally friendly drip irrigation practices. The purpose of this study was to determine the effects of irrigation frequency on soil water depletion and replenishment, root distribution, water deep percolation, soil wetted width and depth, potato yields and water use efficiency.

\section{MATERIALS AND METHODS}

Field experiments were conducted at Agricultural and Veterinary Research Station, Faculty of Agriculture and Veterinary Medicine, AlQassim University during 2003 and 2004 spring seasons. The geographical location of the farm is $26^{\circ} 18^{\prime} \mathrm{N}$ latitude and $43^{\circ} 58^{\prime} \mathrm{E}$ longitude and $725 \mathrm{~m}$ altitude. The average monthly temperature varies between $13{ }^{\circ} \mathrm{C}$ in January and $28.9{ }^{\circ} \mathrm{C}$ in May with relatively low relative humidity table 1 . The calculated average daily evapotrinspiration (ETo-PM) was comparable for the four monthes of the experiment. Soils of the experimental site were deep, sandy soil (96.3 sand, $1.8 \%$ silt and 1.9 clay) with an average bulk density of $1.51 \mathrm{~g} \mathrm{~cm}^{-3}$ and low organic matter content $\left(0.07 \mathrm{~g} \mathrm{~kg}^{-1}\right)$. Gravimetric moisture content varied between $19.5 \%$ at field capacity and $6.5 \%$ at permanent wilting point. Irrigation water, originating from a local well, had.(pH of 7.11and $\mathrm{EC}=1.24 \mathrm{dS} \mathrm{m}^{-1}$ ).

The experiment was set up on $1680 \mathrm{~m}^{2}$ in a randomized block design with four replicates. A buffer zone of $1.2 \mathrm{~m}$ separated between plots to avoid interference. The plot size was $10 \mathrm{~m} \times 4.8 \mathrm{~m}$. Each plot consisted 
of six rows, A spacing of $80 \mathrm{~cm}$ between rows and $25 \mathrm{~cm}$ between plants were maintained.

Table 1. Average Climatic data obtained at the experimental station in 2003 and 2004 seasons and reference evapotranspiration according to Penman Monteth formula.

\begin{tabular}{|l|c|c|c|}
\hline Month & $\begin{array}{c}\text { Air temperature } \\
\left({ }^{\circ} \mathrm{C}\right)\end{array}$ & $\begin{array}{c}\text { Relative humidity } \\
(\%)\end{array}$ & $\begin{array}{c}\text { ETo-PM } \\
\left(\mathrm{mm} \mathrm{day}^{-1}\right)\end{array}$ \\
\hline Jan. & 13.0 & 61.8 & 2.65 \\
\hline Feb. & 14.7 & 54.1 & 2.97 \\
\hline Mar. & 21.5 & 46.3 & 4.5 \\
\hline April & 21.6 & 39.54 & 6.15 \\
\hline May & 28.9 & 32.2 & 8.37 \\
\hline
\end{tabular}

Drip irrigation frequency "IF" means number of irrigation cycles per day (IF $=1 \div$ the duration of one irrigation cycle in days). So, "IF 2/1" means two irrigation cycles per day and "IF1/3" means one third of irrigation cycle per day, or each irrigation cycle covers 3 days. In this research, seven drip irrigation frequencies were applied: (IF 2/1d), (IF1d), (IF1/2), (IF1/3), (IF1/4), IF1/6) and (IF1/8).

The total amount of irrigation water for each of the different treatments of irrigation frequency was equal. The drip irrigation system was installed after the experimental field was ploughed and bedded. Laterals in line drippers (GR) with a flow rate of $2.75 \mathrm{~L} \mathrm{~h}^{-1}$ at 1.0 bar were placed in the center of the raised furrows. Dripper spacing was $20 \mathrm{~cm}$ in the 2003 and 2004 growing seasons. Each plot had one valve, one flow meter, one pressure regulator and one pressure gauge to control the operating pressure and to measure the irrigation quantity. Tests for uniformity of drip system were carried out twice, in the month of January and April, for the two years. For each testing, four drippers from each treatment plot were selected randomly. By collecting the outflow in cans placed below the dripper for a known duration, uniformity of water 
application was determined. CU was found to be $96 \%$ and $95 \%$ for the 2003 and 2004 experimental growth seasons respectively.

In 2003, potato tubers were planted on 15 January, and started emerging about two weeks later. They were harvested on 18 May. In 2004, potato tubers were planted on 12 January, and started emerging about two weeks later. They were harvested on 23 May. The required agriculture practices were carried out as recommended during the growing period in the two experimental sessions.

Reference crop evapotranspiration (ET ${ }_{0}$ ) was calculated on a daily basis by using Penman-Monteith's formula ( $\underline{\text { Smith }}, 1991)$. The necessary weather data were collected from an automatic weather station, $100 \mathrm{~m}$ away from the field site. The actual evapotranspiration was estimated and adjusted at the beginning of each growth stage by multiplying reference evapotranspiration for different months by crop coefficient $\left(\mathrm{ETc}=\mathrm{ET}_{0} \times K_{\mathrm{C}}\right)$ based on crop growth stages. The crop coefficient adopted during the crop season 2003 and 2004 were 0.7 (emergency ; 24 days after sowing) - 0.95 (25; 55 days) - 1.15 (56; 105 days) - 0.75 (106115 days). Potato is a 120-day duration crop and may be divided into four stages, namely initial emerging stage of 24 days, vegetative growth of 30 days, tuber initiation and tuber bulking of 50 days and maturation of 15 days. Crop coefficient at developmental stage was estimated by using the relationship suggested by Allen et al., 1998. Methodology formulated by_Allen et al. (1998) was used for daily irrigation schedule. Irrigation was stopped at the last 5 days for permitting soil to dry before harvesting.

Depth of irrigation water (d) in all treatments was estimated by multiplying actual evapotranspiration (ETc) for different months by the number of days "F" for each irrigation cycle $(\mathrm{d}=\mathrm{ETc} \times \mathrm{F})$, i.e depth of irrigation water for treatment (IF1/3) has to be equal to ETc $x 3$. When it rained, effective rainwater was subtracted from irrigation application. It has to be mentioned here that during the first initial stage during potatoes emerging, all treatments plots were well irrigated for 24 days with the same quantity of water for the irrigation frequency "IF1/1" (irrigating 
every day) in order to ensure a uniform germination rate. After that, each plot was irrigated according to the prescribed frequency treatments.

Time domain reflectometry (TDR) was used in this study for the determination of soil water content. In 2003 and 2004, seven sets of sensors were installed in the seven treatments. Every set of sensors had 35 sensors. Sensors were installed at five points perpendicular to the drip line at $0,10,20,30$ and $40 \mathrm{~cm}$. In 2003 and 2004, the sensors were fixed in the middle depth of $10 \mathrm{~cm}$ intervals up to a depth of $40 \mathrm{~cm}$. and in the middle depth of $20 \mathrm{~cm}$ intervals up to depth $100 \mathrm{~cm}$. Following the emergence of the potatoes, soil moisture content was measured just before irrigation and 2 hours after irrigation. Soil moisture content below $60 \mathrm{~cm}$ was considered as deep percolation losses. The wetted soil in the horizontal direction "W" and the wetted depth "D" under each irrigation were recorded for different irrigation water depths, i.e. for different irrigation frequency treatment.

Root sampling was carried out just before the harvesting day. A hollow auger with an internal diameter of $0.055 \mathrm{~m}$ was used to collect soil cores. Samples were collected at five points perpendicular to the drip line at 0 , $10,20,30$ and $40 \mathrm{~cm}$ such that the center of the standard potato crop was immediately under the dripper. In 2003 and 2004, the samples were extracted at $10 \mathrm{~cm}$ intervals up to a depth of $90 \mathrm{~cm}$. The same process was repeated at four different locations in each treatment plot. Samples of the same depth and horizontal distance for the same treatment were mixed. The samples were used to measure dry root weights. They were measured indoors after the root samples were oven-dried. At harvest time, 120 days after tubers sowing, potato tubers were harvested and weighed.

The crop water use efficiency (CWUE), the field water use efficiency (FWUE) and water consumptive use (root absorption) of potato plant were determined from equations (1), (2) and (3) according to $\underline{\boldsymbol{B} \boldsymbol{e g g}}$ and Turner (1976).

$\mathrm{CWUE}=(\mathrm{Y} / \mathrm{Cu}) \ldots \ldots \ldots \ldots \ldots \ldots \ldots \ldots \ldots \ldots \ldots \ldots \ldots \ldots \ldots \ldots \ldots \ldots \ldots \ldots \ldots \ldots \ldots$
$\mathrm{FWUE}$ 
where:

$$
\mathrm{Cu}=[(\mathrm{Sw}-\mathrm{Si}) / 100] * \lambda * \mathrm{y}
$$

CWUE $=$ crop water use efficiency, $\mathrm{kg} / \mathrm{m}^{3} ;$

FWUE = field water use efficiency, $\mathrm{kg} / \mathrm{m}^{3}$;

$\mathrm{Y}=$ the potato tuber yield, $\mathrm{kg} / \mathrm{m}^{2}$;

$\mathrm{Cu}=$ water consumptive use, $\mathrm{m}^{3} / \mathrm{m}^{2}$;

$\mathrm{Aw}=$ the total amount of applied water, $\mathrm{m}^{3} / \mathrm{m}^{2}$;

$\mathrm{Sw}=$ the soil moisture content after 2 hours of irrigation , \%;

$\lambda=$ the specific bulk density;

$\mathrm{y}=$ the depth of the root zone, $\mathrm{cm}$;

$\mathrm{Si}=$ the soil moisture content just before irrigation, $\%$.

\section{RESULTS AND DISCUSSION}

\section{Effect of irrigation frequency on irrigation water depth.}

Irrigation depths for "IF1/1" after potato planting for (0-15 day),((1624),(25-55),(56-66),(67-90),(91-102) and (103-115day) periods are shown in Fig.1. Irrigation depth increased by increasing air temperature and plants growth. It increased to the highest value $7,073 \mathrm{~mm}$ for the potato buckling period (91-102 days) on April month when temperature was relatively high with the biggest value of crop coefficient 1.15 . For all treatments, the maximum values of irrigation water depths were obtained at the tubers Initiation and buckling. Total irrigation depth for each drip irrigation treatment was 436mm during 2003 and 2004 growing season. All treatments plots were irrigated with the same irrigation water for the first 24 day. After this time the treatments were irrigated according to the values for different frequency. There were 37 different irrigation depths, table (2). The minimum irrigation depth was $1.411 \mathrm{~mm}$ for ( IF2/1) at (2555day) period, while the maximum value was $56.584 \mathrm{~mm}$ for ( IF1/8 ) at (91-102 day) period.

\section{Effect of irrigation water depth on wetted area width "W" and depth "D".}

Fig. (2) shows the relationship between the irrigation depth "d" and both the wetted soil in the horizontal direction "W" and the wetted depths "D". The data revealed that wetted length and depth were affected by 
irrigation water depth. Increasing irrigation water depth increased the length and depth of wetted zone.
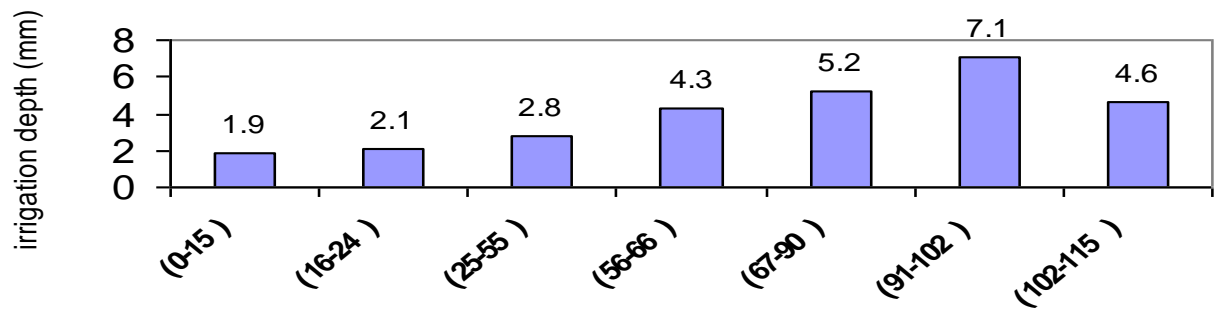

days from planting

Fig.(1): irrigation depths for the IF1/1 treatment (one day irrigation cycle) during the potato plating season

Greater irrigation water depth allows water to move faster both vertically and horizontally. Empirical power equations were derived to estimate wetting length and depth for the sandy soil. The range of equation (3) extended only to $40 \mathrm{~cm}$ distance for the middle furrows. But for the external furrow of each plot, this equation can extend to any distance.

$$
\begin{array}{lll}
\mathrm{W}=23.465 *(\mathrm{~d})^{0.3367} & \mathrm{R}^{2}=0.99 & \text { Eq.(3) } \\
\mathrm{D}=11.274 *(\mathrm{~d})^{0.408} & \mathrm{R}^{2}=0.98 & \text { Eq. (4) }
\end{array}
$$

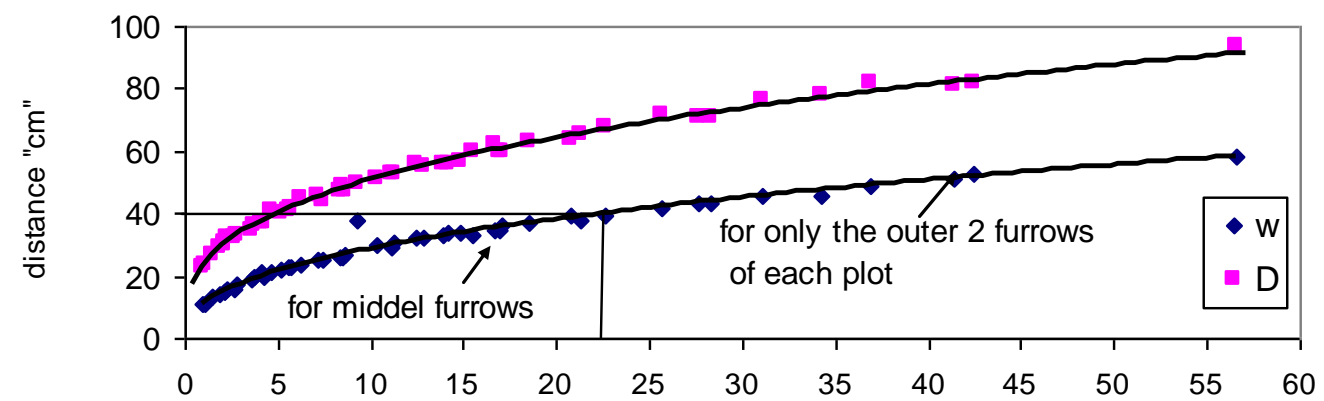

Irrigation water depth "mm"

Fig. (2): Effect of irrigation water depth on wetted area wedith "W" and depth "D" 
Table (2). Irrigation water depths for different planting periods for each irrigation frequency

\begin{tabular}{|c|c|c|c|}
\hline Treatments & Period (days) & Potato stages & $\begin{array}{l}\text { irrigation depths } \\
\text { (mm / irrigation) }\end{array}$ \\
\hline \multirow{5}{*}{ IF $2 / 1$} & $(25-55)$ & \multirow{2}{*}{ Vegetative } & 1.411 \\
\hline & $(56-66)$ & & 2.137 \\
\hline & $(67-90)$ & \multirow{2}{*}{ Tuber initiation and buckling } & 2.587 \\
\hline & $(91-102)$ & & 3.536 \\
\hline & $(103-115)$ & maturation & 2.306 \\
\hline \multirow{7}{*}{$\mathrm{IF} 1 / 1$} & $*(0-15)$ & \multirow{2}{*}{ Initial } & 1.855 \\
\hline & $*(16-24)$ & & 2.079 \\
\hline & $(25-55)$ & \multirow{2}{*}{ Vegetative } & 2.822 \\
\hline & $(56-66)$ & & 4.275 \\
\hline & $(67-90)$ & \multirow{2}{*}{ Tuber initiation and buckling } & 5.175 \\
\hline & $(91-102)$ & & 7.073 \\
\hline & $(103-115)$ & maturation & 4.613 \\
\hline \multirow{5}{*}{$\mathrm{IF} 1 / 2$} & $(25-55)$ & \multirow{2}{*}{ Vegetative } & 5.644 \\
\hline & $(56-66)$ & & 8.550 \\
\hline & $(67-90)$ & \multirow{2}{*}{ Tuber initiation and buckling } & 10.350 \\
\hline & $(91-102)$ & & 14.146 \\
\hline & $(103-115)$ & maturation & 9.226 \\
\hline \multirow{5}{*}{$\mathrm{IF} 1 / 3$} & $(25-55)$ & \multirow{2}{*}{ Vegetative } & 8.466 \\
\hline & $(56-66)$ & & 12.825 \\
\hline & $(67-90)$ & \multirow{2}{*}{ Tuber initiation and buckling } & 15.525 \\
\hline & $(91-102)$ & & 21.219 \\
\hline & $(103-115)$ & maturation & 13.839 \\
\hline \multirow{5}{*}{$\mathrm{IF} 1 / 4$} & $(25-55)$ & \multirow{2}{*}{ Vegetative } & 11.288 \\
\hline & $(56-66)$ & & 17.100 \\
\hline & $(67-90)$ & \multirow{2}{*}{ Tuber initiation and buckling } & 20.700 \\
\hline & $(91-102)$ & & 28.292 \\
\hline & $(103-115)$ & maturation & 18.452 \\
\hline \multirow{5}{*}{$\mathrm{IF} 1 / 6$} & $(25-55)$ & \multirow{2}{*}{ Vegetative } & 16.932 \\
\hline & $(56-66)$ & & 25.650 \\
\hline & $(67-90)$ & \multirow{2}{*}{ Tuber initiation and buckling } & 31.050 \\
\hline & $(91-102)$ & & 42.438 \\
\hline & $(103-115)$ & maturation & 27.678 \\
\hline \multirow{5}{*}{ IF1/8 } & $(25-55)$ & \multirow{2}{*}{ Vegetative } & 22.576 \\
\hline & $(56-66)$ & & 34.200 \\
\hline & $(67-90)$ & Tuher initiation and buckling & 41.400 \\
\hline & $(91-102)$ & Tuber initiation and buckling & 56.584 \\
\hline & $(103-115)$ & maturation & 36.904 \\
\hline
\end{tabular}

Note: * The initial water depths were the same for all other values of irrigation frequency. 
Similar results were obtained from the experimental data by (Li et al., 2003): They indicated that surface wetted length and vertical wetted depth are proportional to the wetted volume applied with power values of about 0.3 and 0.45 respectively for a sandy soil.

\section{Effect of irrigation frequency on root distribution}

Mean values of potato root distribution for the different irrigation frequency treatments in 2003 and 2004 seasons are shown in both Fig.(3) and Fig.(4) by means of root weight density (RWD) for different soil layers. It can be seen from these data that potato roots were concentrated in the $0-40 \mathrm{~cm}$ soil layer for all treatments. The highest root weight density appeared between 0 and $10 \mathrm{~cm}$, where about $51-72 \%$ of the total roots were found in this layer for all treatments.. In the $0-10 \mathrm{~cm}$ layer, RWD was clearly affected by irrigation frequency science with the higher frequency treatments had the lower RWD. The same trend was found for the other soil layer depths. The root weight density decreased by increasing the soil layer depth from $10 \mathrm{~cm}$ to $30 \mathrm{~cm}$ and declined for layer $(40-60 \mathrm{~cm})$. The maximum values of RWD in all layer depths were obtained for the treatment "IF1/8". This might be caused by the effect of longer duration time of irrigation for "IF1/8" which lead to higher soil moisture for potato root which caused higher values for RWD. Statically analyses showed high significant effect of irrigation frequency on RWD.

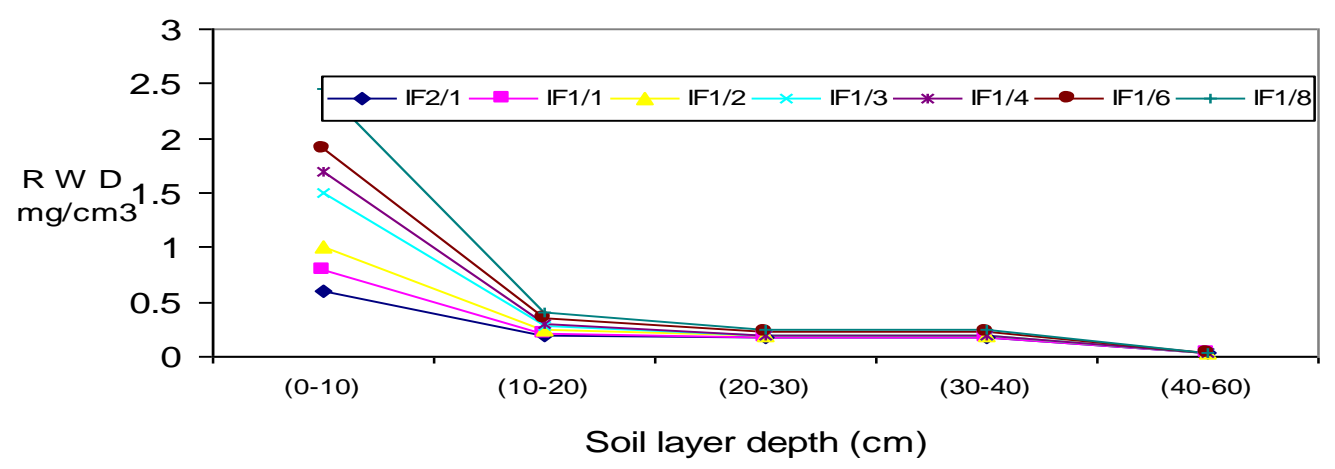

Fig.(3): Effect of irrigation frequancy on root weight density "RwD" for different soil layers. 


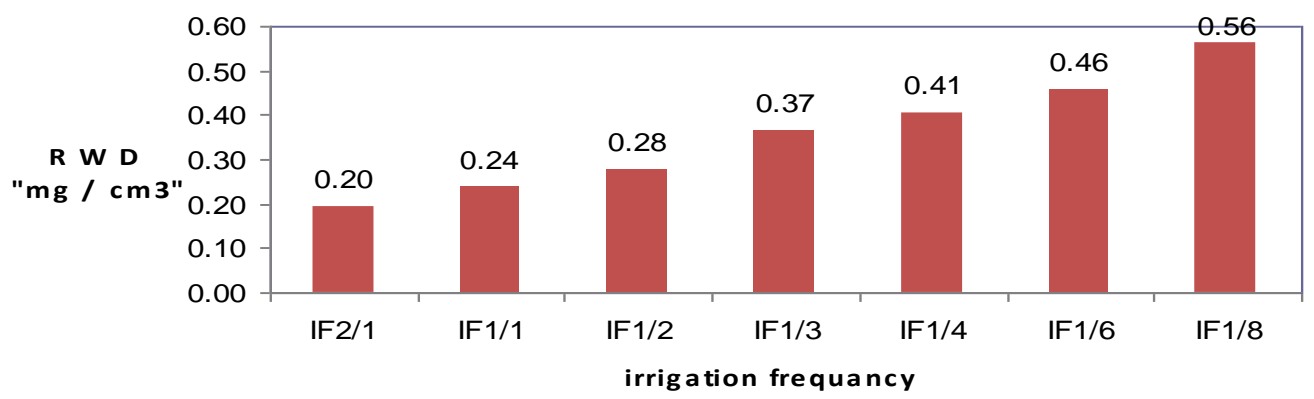

Fig.(4) : E ffect of irrigation frequancy on mean "R WD" in $0-60 \mathrm{~cm}$ layer.

\section{Effect of irrigation frequency on soil moisture distribution}

Fig. 5 illustrates the volumetric soil moisture content at intermediate depths of $10,20,30,40,60,80$ and $100 \mathrm{~cm}$ at immediately positions under the drippers for "IF1/1" , "IF1/3", "IF1/6" and "IF1/8" 2 hours after irrigation and just before next irrigation. The results indicate that soil moisture content in the upper soil layer changed more dramatically than in the lower layer. During the early growth period (25-55 days) after planting, "vegetative growth", the soil moisture content before and after irrigation showed change, but only at depths of 10,20 and $30 \mathrm{~cm}$ with no significant change occurring below the $30 \mathrm{~cm}$ depth for all treatments.

For treatment "IF1/1", the increase in air temperature table (1) and plant age, caused and increase in eavapotraspiration and it irrigation watch depth. The soil moisture content increased at soil layer depth 40 and 60 $\mathrm{cm}$ without any change in the layers of 80 and $100 \mathrm{~cm}$. By increasing the irrigation interval from one day to eight days, soil moisture content increased for the lower layers. Also, by increasing irrigation frequency the soil moisture content before irrigation increased for soil layers 10 to $40 \mathrm{~cm}$. Further analysis of soil water distribution profile indicates that soil moisture content values at soil depths of 60 and $80 \mathrm{~cm}$ became higher with lower irrigation frequencies treatments. This suggests that the irrigation water infiltrating to these depths had not been taken up commensurately as the irrigation amount increased. 


\begin{tabular}{|c|c|c|c|c|c|}
\hline$\bullet-10 \mathrm{CM}$ & $-=20 \mathrm{CM}$ & $30 \mathrm{CM}$ & $-40 \mathrm{CM}$ & $-60 \mathrm{~cm}$ & $\multimap 80 \mathrm{CM}$ \\
\hline
\end{tabular}

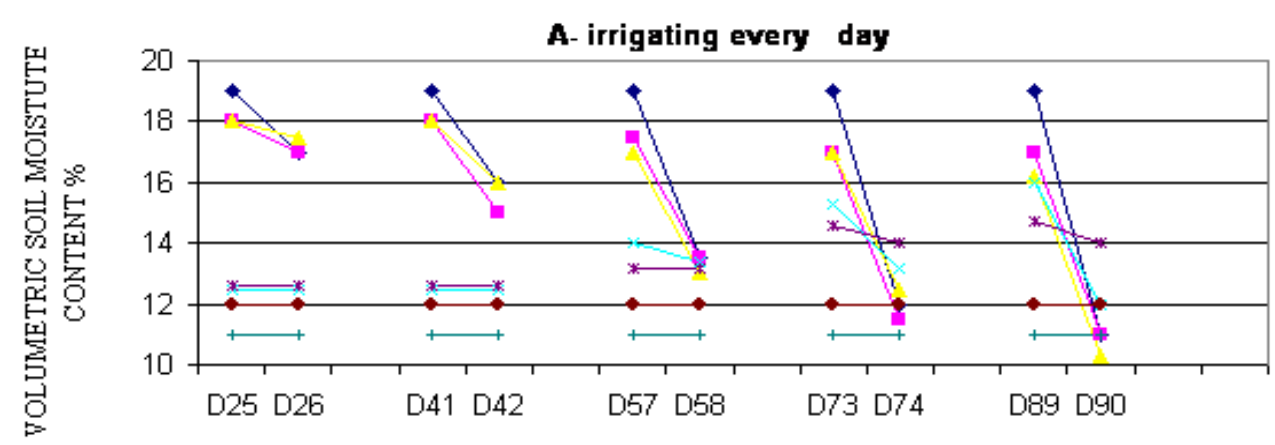

B- irrigating every 3 day

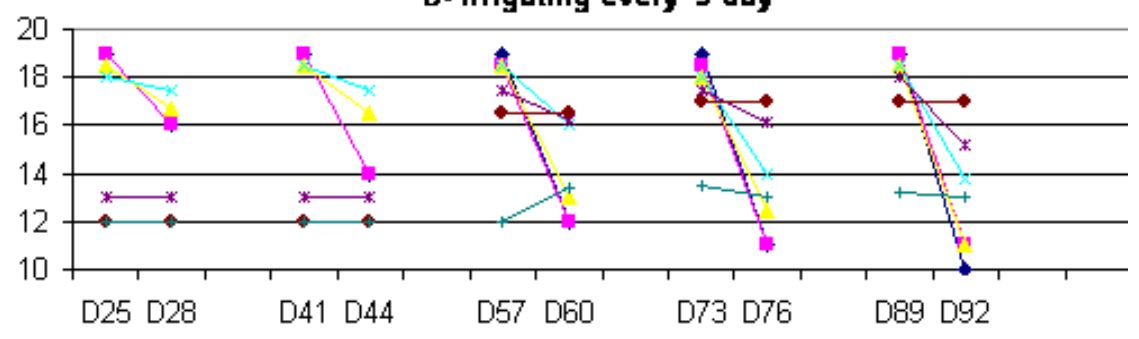

c- irrigating every 6 day

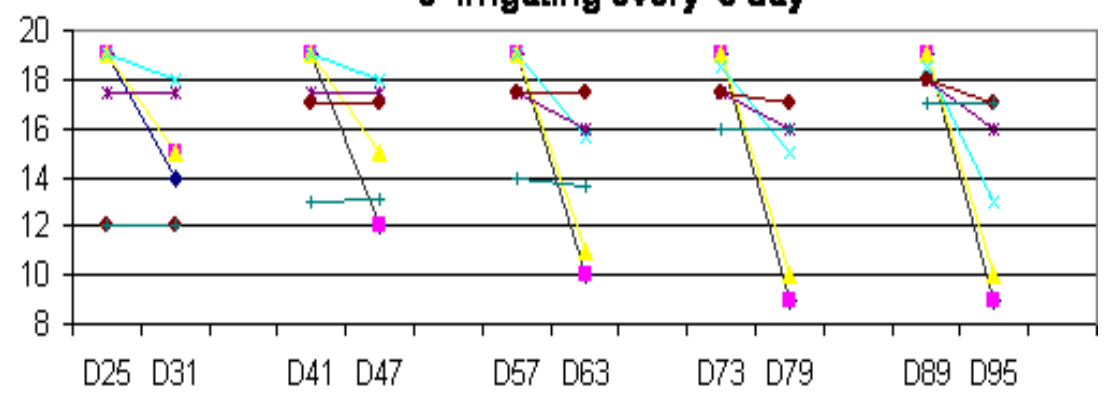

D- irrigating every $B$ day

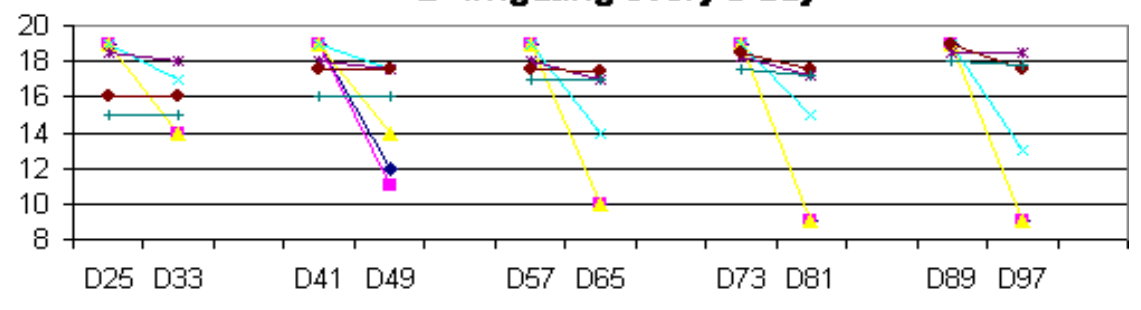

days from planting

Fig. (5): Soil moisture content pattern at different depths under the dripper 2- hours after irrigation and just before next irrigation for different treatment 
The mean values of soil moisture content before irrigation and 2 hours after irrigation in the soil layers $(0-40 \mathrm{~cm})$ for the treatments "IF1/1", "IF1/3", "IF1/6" and "IF1/8" are shown in fig. (6) for 57 and 73 days from potato planting.. The results indicate that soil moisture content in treatment "IF1/6" and "IF1/8" reached the minimum values of soil moisture before irrigation, also they reached the maximum values after irrigation. For irrigation given at the 73 day from potato plating, the soil moisture content reached $8 \%$ and $7 \%$ for "IF1/6" and "IF1/8" treatments, respectively. These values are very close to the value of wilting point $(6.5 \%)$. This low value of soil moisture content caused high water stress on plants for long periods between the successive irrigations, so the yield of potato at theses treatments were dramatically decreased.

To determine the moisture kept for any soil layer "MKL", the measurements values of soil moisture content before irrigation, 2 hours after irrigation, and before next irrigation were used. The values of soil moisture content were measured at five points perpendicular to drip line at $0,10,20,30$ and $40 \mathrm{~cm}$ for layer depth $10 \mathrm{~cm}$. From the field data of soil moisture content, it is noticed that the profile of soil moisture content take a shape of pin in the vertical direction.
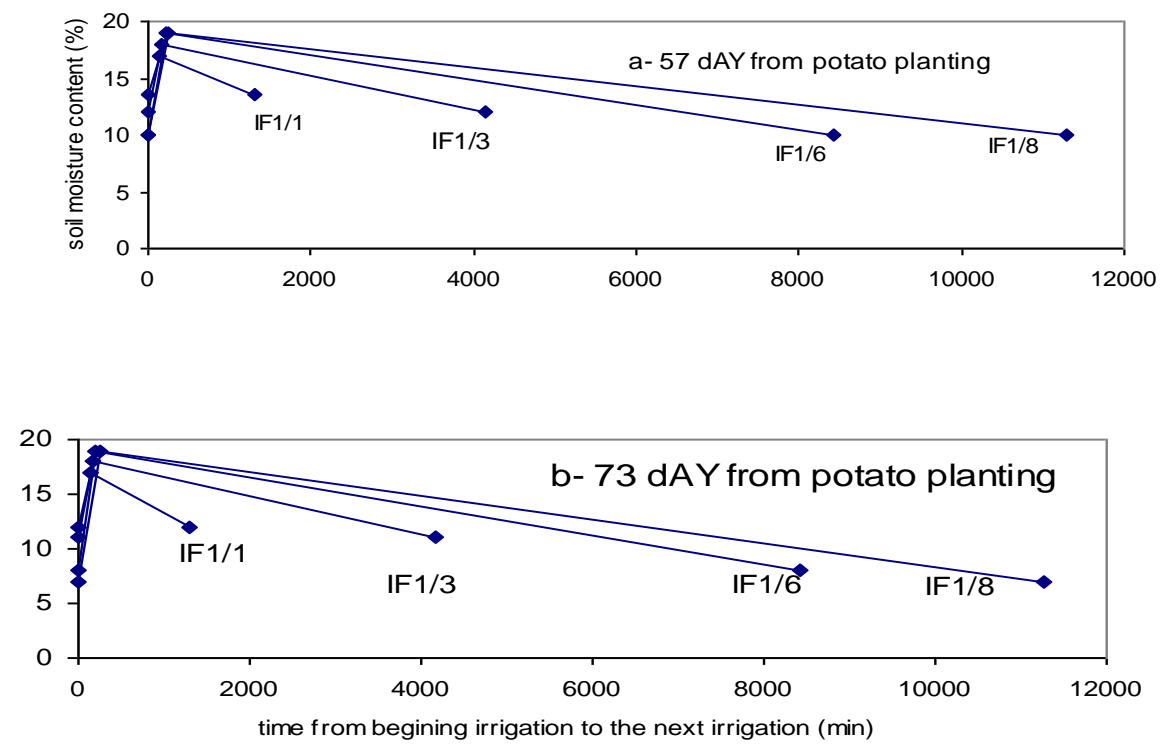

Fig. (6): mean values of soil moisture content before irrigation, 2 hours after irrigation and before next irrigation in $(0-40 \mathrm{~cm})$ layers 
So, the moisture kept in each layer can be determined according to the following steps.

\section{Required data:-}

Wetted length $=\mathrm{L}=20 \mathrm{~cm}$, Wetted width $=\mathrm{W}, 20 \mathrm{~cm}$, Wetted depth $=\mathrm{D}$ "cm" Maximum wetted depth $=100 \mathrm{~cm}$, , Mean volumetric soil moisture content in any soil layer 2 hours after irrigation= $\mathrm{Sw}$ "\%", Mean volumetric soil moisture content in any soil layer before irrigation= $\mathrm{Si}$ "\%"

For any depth in meters "D", the number of soil layers will be ;

No of layers $=(\mathrm{D} /$ the layer depth $)=\frac{D}{0.1}=0.1 D$ Eq. 6

Maximum width in "m" of wetted area $=2 * \mathrm{~W} \quad$ "m"

Average base of the wetted area layer "ui" =

$$
\begin{gathered}
2 * W * \frac{(2 * 0.1 D-(2 i-1))}{2 * 0.1 D} \\
=2 * W *\left(1-\frac{(2 i-1)}{2 * 0.1 D}\right)
\end{gathered}
$$

Where " $\mathrm{i}$ " is a series of numbers from 1 to $\mathrm{n}$.

The steps for determining the moisture kept "MKL 1 " are :.

1- calculate the number of layers from equation "6"

2- calculate the average base width of each layer according to equation "7-a"

3- calculate the volume of each "Vi"

$$
\mathrm{Vi}=2 * W *\left(1-\frac{(2 i-1)}{2 * 0.1 D}\right) * \mathrm{~L} * \text { layer depth }
$$

Where layer depth $=0.1$ meter

$$
\mathrm{L}=0 \text {. meter }
$$

$$
\mathrm{Vi}=0.04 * W *\left(1-\frac{(2 i-1)}{2 * 0.1 D}\right)
$$


4- calculate Moisture kept in layer i "MKLi" =

$$
V i * \frac{S w i-S i i}{200}=\frac{V i}{200} *(S w i-S i i)
$$

The soil moisture kept were determined and shown in fig.(7). Also the percentage of each moisture kept in each layer to all the kept soil moisture are shown in fig.(8). The results indicate that the percentage of soil moisture kept increased by decreasing irrigation frequency from "IF1/1" to "IF1/8" for all soil layers. The percentage of soil moisture kept in the higher layers $(0-20 \mathrm{~cm})$ decreased by decreasing irrigation frequency, then they increased by decreasing irrigation frequency from "IF1/1" to "IF1/8".

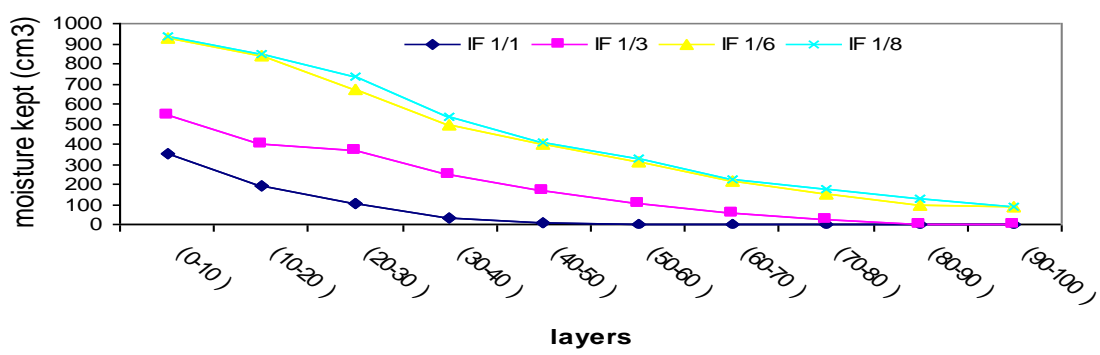

Fig. ( 7 ): moisture kept in different soil layers for the irrigation frequency treatments "IF1/1", "IF1/3", "IF1/6" and "IF1/8" for period (67-90 day).

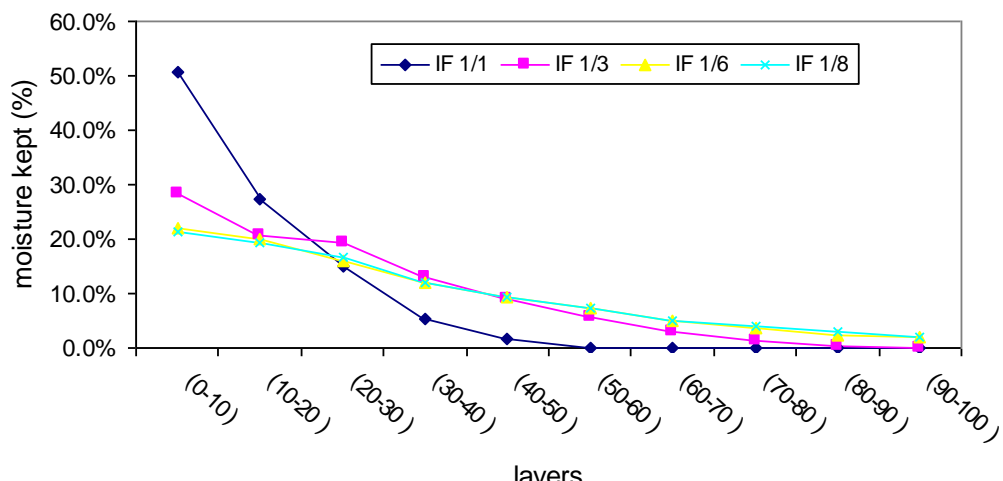

Fig. ( 8 ): percentage of moisture kept in each layer to total moisture kept in all different soil layers for IF $1 / 1$, !F 1/3, IF1/6 and IF1/8 for period (67-90 day) 73 day 


\section{Effect of irrigation frequency on water losses by deep percolation..}

Fig. 9 illustrates the mean seasonal water losses by deep percolation under $60 \mathrm{~cm}$ depth for 2003 and 2004 seasons, for IF2/1, IF1/1, IF1/2, IF1/3, IF1/4, IF1/6 and IF1/8 treatments. The results indicate that irrigation frequency had high significant effect on water losses by deep percolation, L.S.D $=2.96$. Water losses by deep percolation increased by decreasing irrigation frequency. It reached a maximum value of $195 \mathrm{~mm}$ for treatment IF1/8, while the minimum value $5.3 \mathrm{~mm}$ obtained at treatment IF2/1 By increasing the irrigation interval from 0.5 day to 8 days, the depth of irrigation water was increased. Greater irrigation depth over $15 \mathrm{~mm}$ allowed water to more than $60 \mathrm{~cm}$ beyond potato root zone causing big water losses by deep percolation, section 2 fig.(2)

The percentage of total water losses by deep percolation reached $44.72 \%$ of total irrigation water for IF1/8 treatment. So, decreasing the irrigation frequency caused high percentage losses of irrigation water by deep percolation, while increasing irrigation frequency reduced water losses and keep it within the reach of potato root zone.

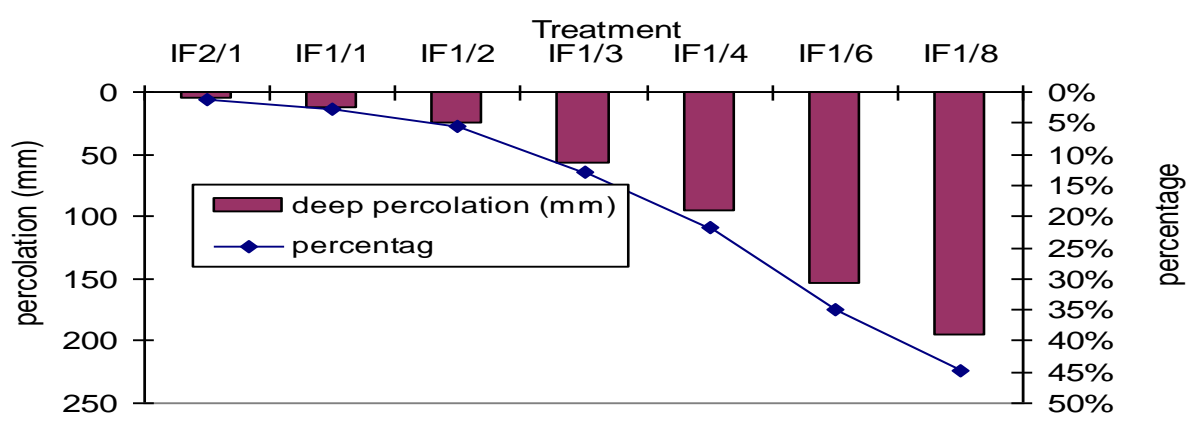

Fig. (9): Effect of irrigation freaquancy on water losses by deep percolation

\section{Effect of irrigation frequency on soil water absorption from different soil layers}

The depletion of water content in the $0-60 \mathrm{~cm}$ depth between the consequent irrigation events was assessed, assuming the absence of water 
rise from the deep groundwater. Table (3). The data revealed that 55 to $66 \%$ of total water used for evapotranspiration was depleted from the upper soil layer $(0-10 \mathrm{~cm})$ layer. This allowed for a speculation on the main root distribution within the upper $10 \mathrm{~cm}$ depth. Significantly, less water was removed from the deeper layers. The most amount of water were occurred from layer $(0-30 \mathrm{~cm})$, where the most potato roots was distributed in this zone layers, section 4 , fig. 3 .

Fig. (10) shows the values of seasonal soil water absorption for different treatments. They reached maximum values of $432.7 \mathrm{~cm}$ and $426 \mathrm{~cm}$ for treatments "IF2/1" and "IF1/1" respectively. While the minimum values were 285 and $243 \mathrm{~cm}$ for treatments IF2/1 and IF1/8, respectively. By increasing the irrigation interval from 0.5 day to 8 days, the seasonal soil water absorption was decreased.

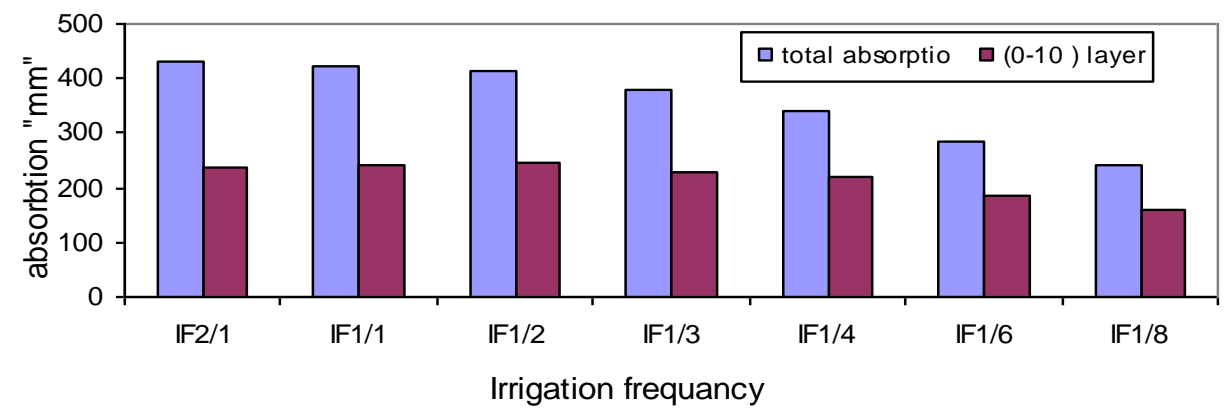

Fig.(10): total soil moisture absorbtion and absorbtion from other soil layer depth (0-10).

\section{Effect of irrigation frequency on potato tuber yield and water use efficiency}

The values of potato yield, field water use efficiency (FWUE) and crop water use efficiency (CWUE) for 2003 and 2004 seasons are shown in table (4). In 2003 season, the yield of potato tubers ranged from 5.1 to 22.4 Ton / ha. The highest yield was at IF1d, 339.2\% more than the lowest yield at IF1/8, The total yield for the seven treatments were in order of $\mathrm{IF} 1 / 1>\mathrm{IF} 1 / 2>\mathrm{IF} 2 / 1>\mathrm{IF} 1 / 3>\mathrm{IF} 1 / 4>\mathrm{IF} 1 / 6>\mathrm{IF} 1 / 8$. IF1/1 was significantly higher than all other treatments according to Duncan's test. 
Table 3. Soil water absorption from different soil layers.

\begin{tabular}{|c|c|c|c|c|c|}
\hline \multirow{2}{*}{ treatment } & \multicolumn{5}{|c|}{ Absorption depth (consumption) "mm" } \\
\cline { 2 - 6 } & $(0-10)$ & $(10-20)$ & $(20-30)$ & $(30-40)$ & $(40-60)$ \\
\hline & 237.05 & 129.30 & 47.41 & 8.62 & 4.31 \\
\hline IF2/1 & 241.68 & 118.72 & 46.64 & 12.72 & 4.24 \\
\hline IF1/1 & 247.20 & 103.00 & 41.20 & 16.48 & 4.12 \\
\hline IF1/2 & 228.00 & 91.20 & 41.80 & 11.40 & 7.60 \\
\hline IF1/3 & 221.65 & 71.61 & 30.69 & 13.64 & 3.41 \\
\hline IF1/4 & 186.78 & 56.60 & 25.47 & 11.32 & 2.83 \\
\hline IF1/6 & 159.06 & 48.20 & 21.69 & 9.64 & 2.41 \\
\hline IF1/8 & 1.73 & 3.65 & 1.96 & 2.20 & 0.95 \\
\hline L.S.D & \multicolumn{5}{|c|}{} \\
\hline
\end{tabular}

Table 4. Potato yield and WUE for different treatments

\begin{tabular}{|c|c|c|c|c|}
\hline Year & Treatment & Potato yield (ton/ha) & $\begin{array}{l}\text { FWUE } \\
\left(\mathrm{kg} / \mathrm{m}^{3}\right)\end{array}$ & $\begin{array}{c}\text { CWUE }(\mathrm{kg} / \mathrm{ha} \mathrm{mm}) \\
\left(\mathrm{kg} / \mathrm{m}^{3}\right)\end{array}$ \\
\hline \multirow[t]{7}{*}{2003} & IF $2 / 1$ & $20.12 \mathrm{c}$ & $4.60 \mathrm{~b}$ & $4.67 c$ \\
\hline & IF1/1 & $22.4 \mathrm{a}$ & $5.13 \mathrm{a}$ & $5.28 \mathrm{a}$ \\
\hline & $\mathrm{IF} 1 / 2$ & $21.1 \mathrm{~b}$ & $4.84 \mathrm{a}$ & $5.12 \mathrm{~b}$ \\
\hline & IF $1 / 3$ & $19.5 \mathrm{~d}$ & $4.47 \mathrm{~b}$ & $5.13 b$ \\
\hline & IF $1 / 4$ & $14.3 \mathrm{e}$ & $3.28 \mathrm{c}$ & $4.19 \mathrm{~d}$ \\
\hline & IF1/6 & $8,6 \mathrm{f}$ & $1.97 \mathrm{~d}$ & $3.04 \mathrm{e}$ \\
\hline & IF $1 / 8$ & $4.6 \mathrm{~g}$ & $1.05 \mathrm{e}$ & $2.12 \mathrm{f}$ \\
\hline \multirow[t]{7}{*}{2004} & IF $2 / 1$ & $19.2 \mathrm{c}$ & $4.40 \mathrm{~b}$ & $1.91 \mathrm{dc}$ \\
\hline & IF1/1 & $23.6 \mathrm{a}$ & $5.41 \mathrm{a}$ & $5.57 \mathrm{a}$ \\
\hline & IF $1 / 2$ & $21.5 \mathrm{~b}$ & $4.93 \mathrm{~b}$ & $5.22 \mathrm{a}$ \\
\hline & IF $1 / 3$ & $18.9 \mathrm{~d}$ & $4.33 \mathrm{~b}$ & $4.97 \mathrm{a}$ \\
\hline & IF1/4 & $13.5 \mathrm{e}$ & $3.09 \mathrm{c}$ & $3.96 \mathrm{~b}$ \\
\hline & IF1/6 & $7.9 \mathrm{f}$ & $1.81 \mathrm{~d}$ & $2.79 \mathrm{c}$ \\
\hline & IF1/8 & $4.8 \mathrm{~g}$ & $1.10 \mathrm{e}$ & $1.99 \mathrm{~d}$ \\
\hline
\end{tabular}

$\S$ Values in a column with the same letter are statistically homogeneous by Duncan's test. 
The yield difference between any other two treatments was significant. In 2004 season, the yield of potato tubers followed the same changing pattern as tuber yield of 2003 season. In both seasons, there was a tendency that tuber yield decreased as irrigation frequency declined., the yields of IF1/1 and IF2/1 were very close, while there was a sharp yield reduction for IF1/4, IF1/6 and IF1/8.

The field water use efficiency (FWUE) increased as the irrigation frequency decreased from IF2/1 to IF1/1but it decreased as the irrigation frequency decreased less than IF1d. IF1/1and IF1/2 were significantly higher than all other treatments according to Duncan's test. The minimum value of field water use efficiency was obtained at IF1/6 and IF1/8. While the maximum value of water use efficiency was obtained at IF1d. The crop water use efficiency (CWUE) had the same trend of the field water use efficiency (FWUE). The minimum value of the crop water use efficiency was $1.91 \mathrm{~kg} / \mathrm{m}^{3}$ for the treatment IF1/8, while the maximum values of crop water use efficiency were 5.28, 5.12 and 5.13 for treatments IF1/1, IF $1 / 2$ and IF1/3, respectively. CWUE of treatment IF1/1was significantly higher than all other treatments

In 2004 season, the data of potato yield, FWUE and CWUE had the same trend of those for 2003 season. From the above mentioned discussion, it is clear that the highest values of potato yield, field water use efficiency and crop water use efficiency were obtained for irrigation frequency IF1/1 then IF $1 / 2$ and IF1/3. So, the irrigation frequency IF1/1 is the suitable one for irrigating spring potato planted in sand soil as that in Qassim zone. Also, irrigating spring potato every two days and three days had significant effect on the potato yield. Irrigating every 4 days or more had very bad effect on potato yield.

\section{CONCLUSION}

The current study was carried out at Agricultural and Veterinary Research Station, Faculty of Agriculture and Veterinary Medicine, Qassim University, Kingdom of Saudia Arabia during 2003 and 2004 spring growing seasons. The objective of this study was to investigate the effect of irrigation frequency on irrigation water depth, wetted area 
width and depth, potato root distribution, soil moisture distribution, water losses by deep percolation, potato tuber yield and water use efficiency. Treatments consisted of seven different drip irrigation frequency. All treatments received the same total amount of drip irrigation water.

The results showed that:

1. Water irrigation depth increased by increasing air temperature and plants growth By decreasing the irrigation frequency, the irrigation water depth increased. The minimum irrigation depth was $1.411 \mathrm{~mm}$ for $\quad($ IF2/1) at (25-55day) period, while the maximum value was $56.584 \mathrm{~mm}$ for ( IF1/8 ) at (91-102 day) period.

2. Wetted width and depth were affected by irrigation water depth "d". By increasing irrigation water depth, width "W" and depth "D" of wetted zone increased. Greater irrigation water depth allows water to move faster both vertically and horizontally. Power equations were fitted to estimate wetting width and depth.

$$
\begin{array}{ll}
\mathrm{W}=23.465 *(\mathrm{~d})^{0.3367} & \mathrm{R}^{2}=0.9965 \\
\mathrm{D}=11.274 *(\mathrm{~d})^{0.408} & \mathrm{R}^{2}=0.9864
\end{array}
$$

3. Potato roots were concentrated in the $0-40 \mathrm{~cm}$ soil layer for all treatments. The range of $51-72 \%$ of the total roots were found in the 0-10 soil layer for all treatments.. Root weight density "RWD" was clearly affected by irrigation frequency where the higher frequeny treatment had the lower RWD values,

4. Soil moisture content in the upper soil layer changed more dramatically than in the lower layer. By decreasing the irrigation frequency soil moisture content increased for the lower layers

5. Seasonal water losses by deep percolation increased by decreasing irrigation frequency. It reached a maximum value of $195 \mathrm{~mm}$ for treatment IF1/8, while the minimum value of $5.3 \mathrm{~mm}$ obtained at treatment IF2/1

6. Seasonal soil water absorption was affected by irrigation frequency, it reached maximum values of $432.7 \mathrm{~cm}$ and $426 \mathrm{~cm}$ 
for treatments IF2/1and IF1/1, respectively, while the minimum values were 285 and $243 \mathrm{~cm}$ for treatments IF1/6 and IF1/8 respctively. Maximum amount of water absorption occurred whithin layers $(0-30 \mathrm{~cm})$

7. The total yield for the seven treatments were in order of $\mathrm{IF} 1 / 1>\mathrm{IF} 1 / 2>\mathrm{IF} 2 / 1>\mathrm{IF} 1 / 3>\mathrm{IF} 1 / 4>\mathrm{IF} 1 / 6>\mathrm{IF} 1 / 8$. IF1/1 was significantly higher than all other treatments according to Duncan's test. The yield difference between any other two treatments was significant.

8. FWUE and CWUE of treatment IF1/1 was significantly higher than those of all other treatments.

\section{REFERENCES}

Allen, R.G., Pereira, L.S., Raes, D., Smith, M., 1998. Crop evapotranspiration. Guidelines for computing crop water requirements. FAO irrigation and Drainage Paper No. 56, FAO, Rome, Italy, p. 300.

Clothier, B.E and S.R Green, 1994. Rootzone processes and the efficient use of irrigation water, Agric. Water Manage. 25 (5): 1-12.

Coelho, E.F. and D. Or. 1996. A parametric model for two-dimensional water uptake by corn roots under drip irrigation, Soil Sci. Am. J. 60 (4): 1039-1049.

Coelho, E.F. and D. Or. 1999. Root distribution and water uptake patterns of corn under surface and subsurface drip irrigation, Plant Soil 206 (2): 123-136.

Dalvi, V.B., K.N. Tiwari, M.N. Pawade and P.S. Phirke.1999. Response surface analysis of tomato production under microirrigation, Agric. Water Manage. 41 (8): 11-19.

Doorenbos, J. and A. H. Kassam. 1979. Yield response to water. FAO Irrigation and Drainage Paper No. 33, FAO, Rome, Italy, p. 181

Mantell, A., H. Frenkel and A. Meiri 1985. Drip irrigation of cotton with saline sodic water, Irrig. Sci. 6 (1): 95-106. 
Meshkat, M., R.C. Warner and S.R. Workman. 2000. Evaporation reduction potential in an undisturbed soil irrigated with surface drip and sand tube irrigation, Trans. ASAE 43 (1): 79-86.

Pitts D.J., Y.J. Tsai, T.A. Obreza and D.L. Myhre.1991. Flooding and drip irrigation frequency effects on tomatoes in South Florida, Trans. ASAE 34 (3): 865-870.

Segal E., A. Ben-Gal and U. Shani. 2000. Water availability and yield response to high-frequency micro-irrigation in sunflowers, Proceedings of the Sixth International Micro-irrigation Congress on 'Micro-irrigation Technology for Developing Agriculture', Conference Papers, 22-27 October South Africa.

Sharmasarkar, F.C., S.D. Miller, G.F. Vance and R. Zhang. 2001 Assessment of drip irrigation and flood irrigation on water and fertilizer use efficiencies for sugarbeets, Agric. Water Manage. 46 (2): 241-251.

Smith, M.1991. Report on the expert consultation on procedures for revision of FAD guidelines for prediction of crop water requirements, FAD, Rome Italy p. 45.

Schwartzman M. and B. Zur.1986. Emitter spacing and geometry of wetted soil volume, J. Irrig. Drain. Eng. 112 (3): 242-253

الملخص العربيى

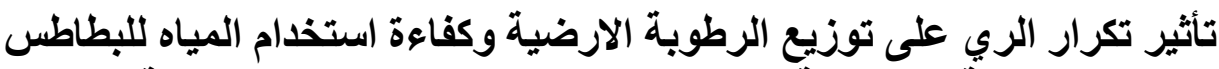

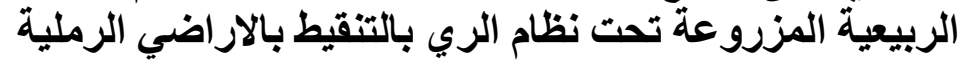

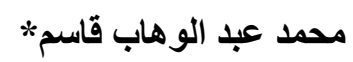

أجريت هذه الدراسة الحقلية بمحطة التجارب الزر اعية و البيطرية بكلية الزر اعة و الطب البيط البيطري

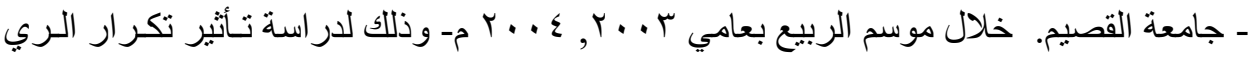

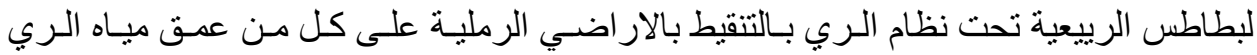

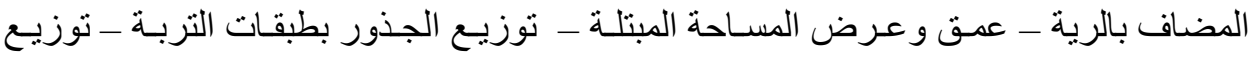

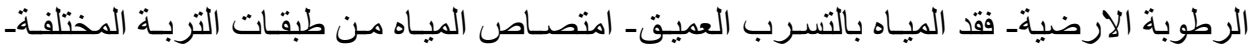

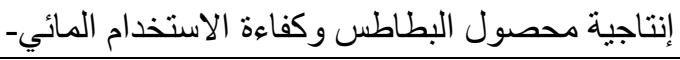
* أستاذ مساعد بقسم الهندسة الزر اعيةـ كلية الزر اعةـ جامعة القاهرة. 


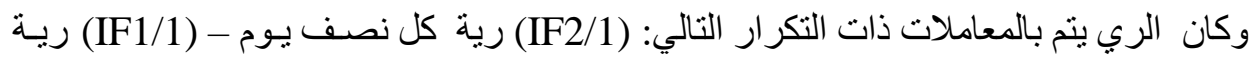

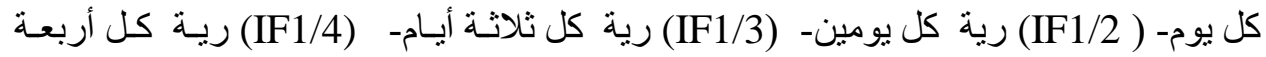

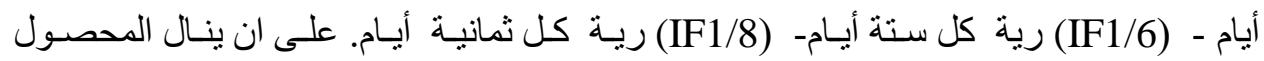

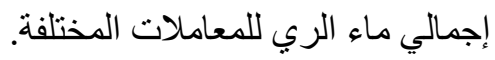

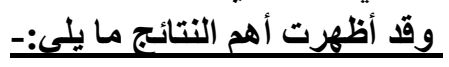

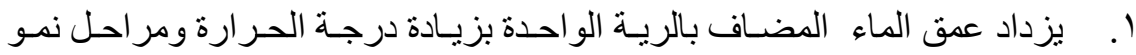

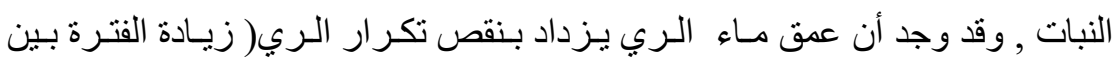

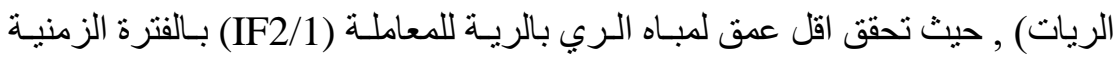

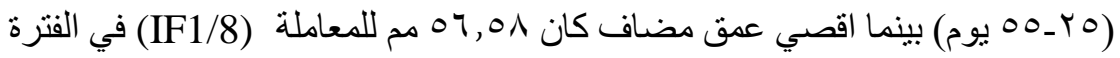

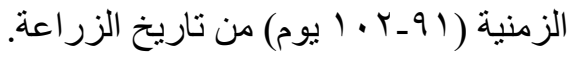

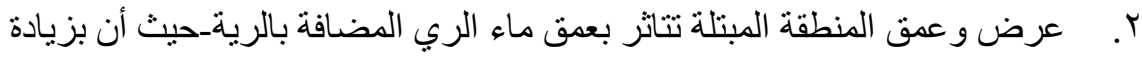

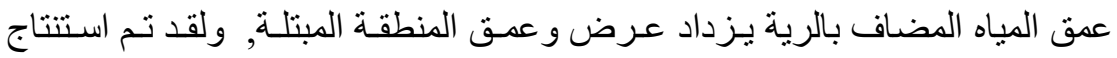

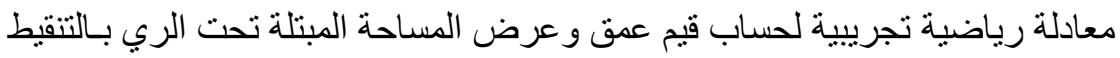

$$
\begin{aligned}
& \text { في الار اضي الرملية وكانت هذه المعادلات هي:- } \\
& \mathrm{W}=23.465 *(\mathrm{~d})^{0.3367} \quad \mathrm{R}^{2}=0.99 \\
& \mathrm{D}=11.274 *(\mathrm{~d})^{0.408} \quad \mathrm{R}^{2}=0.98
\end{aligned}
$$

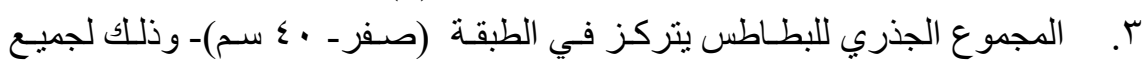

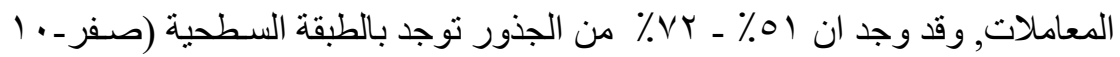

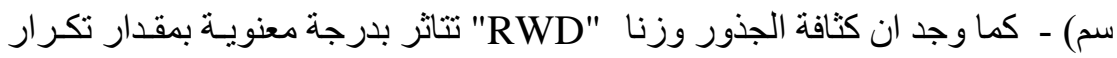

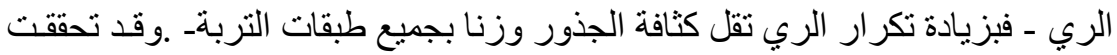

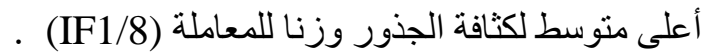

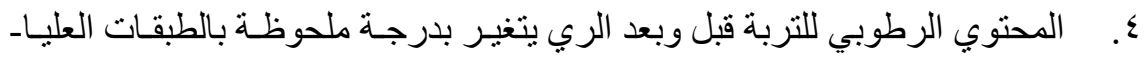

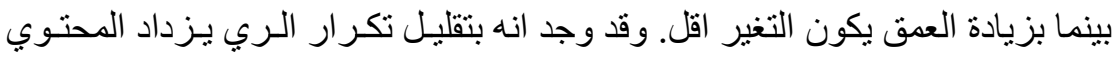

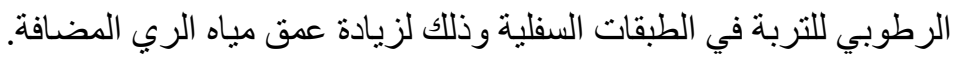

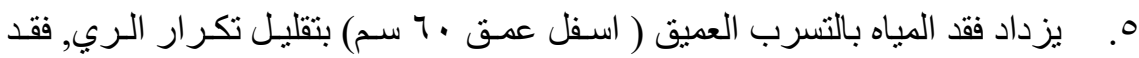

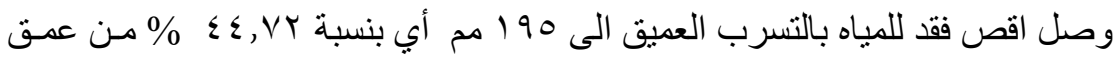

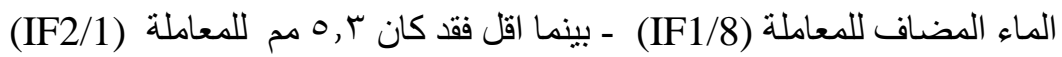

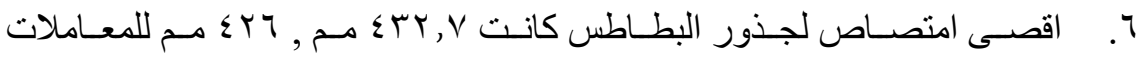

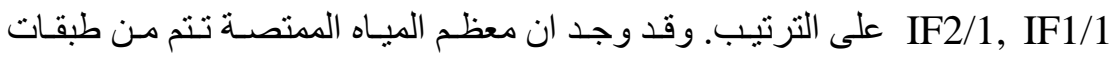

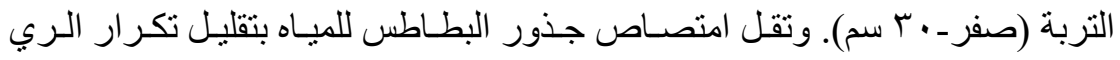

حيث تصل الى اقل امتصاص للمياه للمعاملة IF1/8.

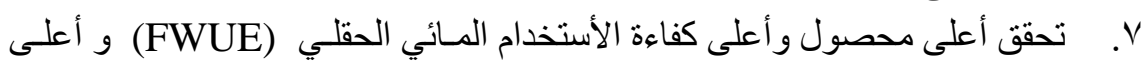

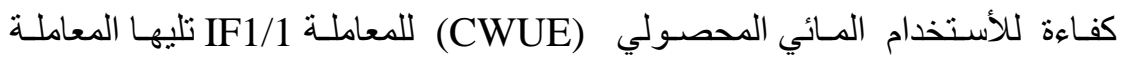

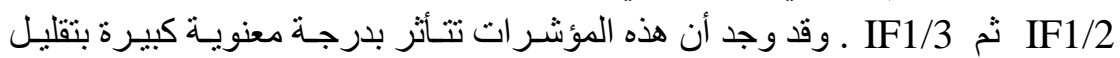

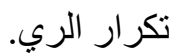

